\title{
Pituitary-Gonadal Relations in Male Children and Adolescents
}

\author{
Jeremy S. D. Winter ${ }^{[60]}$ and Charles Faiman \\ Departments of Pediatrics and Physiology, University of Manitoba, and the Endocrine-Metabolic Sections of the Children's Hospital of \\ Winnipeg and the Winnipeg General Hospital, Winnipeg, Manitoba, Canada
}

\section{Extract}

Data are provided on levels of circulating follicle-stimulating hormone (FSH), luteinizing hormone $(\mathrm{LH})$, and testosterone in healthy male children and adolescents, and these levels are correlated with the stage of sexual maturation, bone maturation, whole body ${ }^{4} \mathrm{~K}$ content, and the 24 -hr excretion of creatinine, estrogens, 17-hydroxycorticosteroids, total 17-ketosteroids, and fractionated 11-deoxy-17-ketosteroids (see Tables I and II).

Before age 6 there was no significant change with age in testis size or hormone concentrations. From age 6-10 years there was a gradual rise in testis size (Fig. 1), serum FSH (Fig. 4) and serum LH (Fig. 3), but no change in plasma testosterone (Fig. 2), which remained below $40 \mathrm{ng} / 100 \mathrm{ml}$. From age 11-17 years there was a doubling of mean testis length, continued rise in serum FSH, and a steeper rise in LH; these changes were accompanied by a 20 -fold increase in plasma testosterone concentration, the appearance of male secondary sexual characteristics (Figure 5), more rapid bone maturation and whole body ${ }^{40} \mathrm{~K}$ accretion, and enhanced excretion of estrogens and 11-deoxy-17-ketosteroids. Mean levels of FSH in the adult range ( $>10 \mu \mathrm{g} / 100$ ml) were achieved by age 8 , and levels reached a plateau by age 15 (Fig. 6). Adult $\mathrm{LH}$ levels $(>2.5 \mu \mathrm{g} / 100 \mathrm{ml})$ were reached by age 13 and a plateau was observed after 17 years. Plasma testosterone also ceased to rise after age 17.

The data suggest that the testis may undergo progressive gonadotropin-mediated maturation in late childhood. Testosterone secretion by the Leydig cells at puberty may result from a further rise in LH levels.

\section{Speculation}

Pituitary secretion of gonadotropins, particularly FSH, in male children is a gradual phenomenon, antedating by several years the release of testosterone by the testis. This gradual rise may represent a progressive reduction in hypothalamic sensitivity to feedback by testicular steroids other than testosterone. In late childhood, rising FSH and LH levels may induce increased activity of the enzymes responsible for both synthesis and catabolism of testosterone. At puberty, an LH-mediated reduction in reductase activity might then result in testosterone accumulation and secretion.

\section{Introduction}

The present availability of sensitive and specific isotope displacement assays for circulating levels of go- nadotropins and steroid hormones in man permits a reevaluation of the pituitary and Leydig cell changes which initiate and maintain normal male sexual devel- 
opment. Recent reports have demonstrated that concentrations of testosterone in plasma $[2,13,14,39,50]$ and urine $[15,22,29,49]$ of boys are considerably lower than those found in adolescent and adult males. Furthermore, plasma testosterone concentrations appear not only to be low but also unchanging during childhood. With the initiation of somatic adolescence, there is a steep rise in testosterone levels, closely paralleling the observed pubertal changes [13]. Several authors have demonstrated measurable gonadotropin levels in serum $[5,18,26,53]$ and in urine $[11,24,35$, $43]$ of prepubertal males, but the relation of these levels to testosterone secretion has not been clearly eludicated.

Some authors $[3,43]$ have reported gradually rising excretion of luteinizing hormone $(\mathrm{LH})$ in urine of males during childhood, with a more abrupt 2-fold increase at puberty. Buckler and Clayton [4] showed low LH excretion levels from age 3 months to 6 years, after which gradually rising levels were seen, with a further marked increase at puberty. Raiti et al. [35] found a progressive increase in follicle-stimulating hormone (FSH) excretion after age 5 years, with a further more abrupt pubertal rise. It appears, therefore, that excretion of gonadotropins in urine is rising in boys long before testosterone-mediated signs of puberty become apparent.

Excretion studies discount possible changes in the renal clearance of gonadotropins with age, and serum concentrations may provide a more valid reflection of secretion rates, particularly at low levels [3]. Various authors have used radioimmunoassay techniques to measure $\mathrm{FSH}$ and $\mathrm{LH}$ concentrations in serum of male children and adolescents $[5,21,26,31,34,36,38$, $40-42,53,54]$. Although the absolute values from these studies are not strictly comparable because of different standards and antisera used, most authors agree that circulating gonadotropin levels are higher in pubertal than in prepubertal males, with, however, some overlap between the groups. Lee et al. [26] and Yen et al. $[53,54]$ suggest that serum FSH and LH levels do not change until puberty, at which time there is a 2- to 3 -fold rise in the concentration of each. On the other hand, Johanson et al. [18] and Raiti et al. [34] suggest that levels begin to rise after age 9 , with a steeper rise at puberty. Most authors agree that serum gonadotropin levels continue to rise throughout the various clinical stages of puberty, but only Wieland et al. (50) have correlated gonadotropin concentrations with levels of circulating testoterone. There is therefore some disagreement in the literature regarding the tim- ing of the pituitary phenomena associated with puberty.

It is the purpose of this report to provide data on levels of circulating $\mathrm{FSH}, \mathrm{LH}$, and testosterone in healthy male children and adolescents, and to correlate these data with commonly used physical, radiologic, and laboratory parameters of growth and sexual development. The data support the concept that pituitary gonadotropin release increases several years before puberty. This finding raises various questions about the nature of the feedback systems operant in childhood and the mechanisms involved in initiating adolescence.

\section{Materials and Methods}

\section{Subjects}

The 253 subjects in the study included: 60 school student volunteers taking part in a longitudinal growth-research program; 21 university students, 41 residents of a training school for mildly retarded children; and 132 patients of the Children's Hospital. All were judged to be free of endocrine disease by history and physical examination. As there was no significant difference in the age-specific means for any variable among the four groups, the data have been pooled. Informed written consent was obtained from all subjects (when possible) as well as from their parents or guardians, or both.

Each subject's pubertal development was assessed from phallic length, mean testicular length, and the amount and distribution of pubic and axillary hair. Pubertal stages were assigned as: $P_{1}$ : prepubertal in all respects, with longest testis diameter less than $2.4 \mathrm{~cm}$; $P_{2}$ : early testicular enlargement (diameter $2.4-3.2 \mathrm{~cm}$ ), sometimes associated with sparse hair at the base of the penis; $P_{3}$ : testis diameter $3.3-4.0 \mathrm{~cm}$, obvious pubic hair, beginning phallic enlargement and possibly early but sparse axillary hair; $P_{4}$ : testis diameter $4.1-4.5 \mathrm{~cm}$, pubic hair of adult amount, moderate axillary hair; $P_{5}$ : testis diameter greater than $4.5 \mathrm{~cm}$ and adult secondary sexual characteristics.

In the school-age subjects an estimate of lean body mass was obtained with the whole body ${ }^{40} \mathrm{~K}$ counting facilities of the Whiteshell Nuclear Research Establishment. Each subject was counted in a lead, copper, and steel-lined room, for 3 10-min periods, with an 11.5inch diameter, 4-inch thick sodium iodide crystal located 9.5 inches above the chest, hips, and thighs, respectively. The output from the photomultiplier tubes was recorded by a multichannel pulse-height analyzer 
and the counts in the ${ }^{40} \mathrm{~K}$ photo peak were integrated by computer. Because of conflicting data on the effects of body size and age on counting geometry and self-absorption, and the paucity of accurate information on lean body potassium concentration in children of different ages, we have presented the ${ }^{40} \mathrm{~K}$ data as raw $\mathrm{cpm}$. (Preliminary investigations with this scintillation counter suggest that counting efficiency is not constant with changing body size. However, if one assumes constant efficiency and lean body $\mathrm{K}$ concentration of 68.1 $\mathrm{mEq} / \mathrm{kg}$ [12], an approximate lean body mass in kilograms can be obtained by dividing the ${ }^{40} \mathrm{~K} \mathrm{cpm}$ by 2.9.)

Skeletal maturation was determined in each subject from $x$-rays of both hands and wrists, using the standards of Tanner et al. [47].

Blood was drawn from all subjects between $10 \mathrm{AM}$ and 1 PM on the examination day, and serum and plasma aliquots were frozen at $-20^{\circ}$ until analyzed. In addition, 78 subjects provided a 24-hr urine sample, which was also stored at $-20^{\circ}$ until analyzed.

\section{Laboratory Methods}

Serum LH and FSH levels were measured in duplicate by the double antibody radioimmunoassay techniques of Faiman and Ryan [9, 10], in sample volumes of $0.2 \mathrm{ml}$ serum for adults and $0.4 \mathrm{ml}$ for children. A crude human pituitary gonadotropin preparation, LER-907 [55], was used as the standard in both assays. (The FSH and LH data in this report (micrograms LER-907 per $100 \mathrm{ml}$ ) may be converted to milli-international units 2nd IRP-HMG per milliliter by multiplying the FSH value by 0.5 and the $\mathrm{LH}$ value by 4.5 .) The minimum levels detectable in a 0.4-ml sample averaged 3.1 and $0.8 \mu \mathrm{g}$ LER-907/100 $\mathrm{ml}$ for FSH and $\mathrm{LH}$, respectively. Samples reading below the limit of sensitivity for $\mathrm{LH}$ were assigned a value of $0.8 \mu \mathrm{g} / 100$ $\mathrm{ml}$. The coefficient of variance for duplicate determinations at low serum concentrations at the time of the study were $\pm 6.3 \%$ for $\mathrm{LH}$ and $\pm 4.9 \%$ for FSH. A low value control serum pool was repetitively assayed over the course of 1 year; the mean values $( \pm \mathrm{SD}$ ) were $2.9 \pm 0.5$ for $\mathrm{LH}$ and $11.0 \pm 1.6$ for FSH.

Plasma testosterone concentration was measured in duplicate by the competitive protein-binding technique of Winter and Grant [52] in a sample volume of $0.25 \mathrm{ml}$ for adults and $2.5 \mathrm{ml}$ for children. The sensitivity of the assay was $0.15 \mathrm{ng}$, corresponding to the upper $95 \%$ confidence limit for testosterone-free samples. In this study, samples reading below $0.15 \mathrm{ng}$ in $2.5 \mathrm{ml}$ plasma have been assigned an arbitrary value of
$6 \mathrm{ng} / 100 \mathrm{ml}$. The coefficient of variation, determined from the duplicate samples in this report, was $6.3 \%$.

The 24-hr excretions of creatinine, total 17-ketosteroids (17-KS) [32], and 17-hydroxycorticosteroids (17-OHCS) [46] were determined by standard methods. Individual 11-deoxy-17-ketosteroids were measured by the gas-liquid chromatographic method of Jungmann et al. [20]. Total urinary estrogens were determined by the method of Eechaute and Demeester [7], as modified by van Baelen et al. [48].

\section{Results}

The clinical and laboratory data for each 2-year age period are shown in Table $I$ and the hormone results for each developmental stage are summarized in Table II. PIasma testosterone was not measurable $(<6 \mathrm{ng} \%)$ in 5 children, all below 11 years of age. Follicle-stimulating hormone was measurable in all subjects. Luteinizing hormone was below the level of sensitivity $(0.8$ $\mu \mathrm{g} / 100 \mathrm{ml}$ ) in four subjects, all below age 6 .

\section{The Preadolescent Years}

Below age 10 all of the boys were clinically prepubertal (stage $P_{1}$ ). Mean phallic size increased gradually throughout childhood. Testis size (Fig. 1) changed little before age 6 ; from age 6 to 10 years there was a gradual increase in mean testis length $(r=0.48, P<$ $0.001)$. There was no significant change in plasma testosterone concentration (Fig. 2) during childhood $(r=$ $0.18, P>0.1$ ), with all values below $40 \mathrm{ng} / 100 \mathrm{ml}$. Serum LH (Fig. 3) and FSH (Fig. 4) concentrations did not change before age 6 ; however, there was a gradual but significant rise in both between 6 and 10 years $(r$ $=0.55$ and 0.53 , respectively; $P<0.001$ ). This pattern closely resembled that seen for testis growth in late childhood.

\section{Puberty}

The earliest recognizable sign of puberty was more rapid testicular enlargement which usually preceded any signs of androgen effect. This has been identified as stage $P_{2}$; the mean chronologic age at this stage was 11.8 years (range 9.6-15.1) and the mean bone age was 11.9 years (range 10.5-13.5). Boys in this stage showed significantly higher FSH, LH, and testosterone levels than did the prepubertal subjects. Between age 10-17 years there was an approximately 20 -fold increase in plasma testosterone. This was accompanied by more rapid phallic growth and the appearance of pubic and axillary hair (Fig. 5). The anabolic action of testoster- 
Table $I$. Circulating gonadotropin and testosterone levels, urinary steroid excretion, bone maturation and whole body ${ }^{40} \mathrm{~K}$ content in 253 males in relation to age and sexual development

\begin{tabular}{|c|c|c|c|c|c|c|c|c|c|c|c|c|c|c|c|c|c|}
\hline \multirow[b]{2}{*}{ Age, yr } & \multicolumn{4}{|c|}{ Clinical data } & & & & \multicolumn{7}{|c|}{ 24-hr urine content } & \multicolumn{2}{|c|}{ Serum } & \multirow{2}{*}{$\begin{array}{c}\text { Plasma } \\
\begin{array}{c}\text { Testosterone } \\
\text { ng/100 ml }\end{array}\end{array}$} \\
\hline & No. & $\begin{array}{c}\text { Puberty } \\
\text { stage }^{1}\end{array}$ & $\begin{array}{c}\text { Testis } \\
\text { diameter, } \\
\mathrm{cm}\end{array}$ & $\begin{array}{c}\text { Penis } \\
\text { length, } \\
\mathrm{cm}\end{array}$ & $\left|\begin{array}{c}\text { Bone } \\
\text { matura } \\
\text { tion score } \\
{[47]}\end{array}\right|$ & ${ }^{40} \mathrm{~K}, \mathrm{cpm}$ & $\begin{array}{c}{ }^{40} \mathrm{~K} \\
\mathrm{cpm} / \mathrm{kg}\end{array}$ & $\underset{\mathrm{g}}{\text { Creatinine }}$ & $\underset{\substack{\text { Total } \\
17-\mathrm{KS}, 2}}{\mathrm{mg}}$ & $\begin{array}{l}\text { Andro- } \\
\text { sterone, } \\
\text { mg }\end{array}$ & $\begin{array}{l}\text { Etiochol- } \\
\text { anolone, } \\
\text { mg }\end{array}$ & $\underset{\mathrm{mg}}{\mathrm{DHA},{ }^{2}}$ & $\underset{\mu \mathrm{g}}{\text { Estrogens, }}$ & $\underset{\mathrm{mg}}{\mathrm{OHCS}^{17-}}$ & \multicolumn{2}{|c|}{$\mu \mathrm{g}$ LER-907/100 $\mathrm{ml}$} & \\
\hline $0.2-2.0$ & 11 & $p_{1}$ & $1.4 \pm 0.4^{7}$ & $2.7 \pm 0.5$ & $8 \pm 7$ & & & & & & & & & & $7.0 \pm 2.4$ & $1.2 \pm 0.4$ & $13 \pm 10$ \\
\hline $2.1-4.0$ & 7 & $P_{1}$ & $1.2 \pm 0.4$ & $3.3 \pm 0.4$ & $53 \pm 16$ & & & & & & & & & & $7.5 \pm 1.4$ & I. $3 \pm 0.6$ & $11 \pm 4$ \\
\hline $4.1-6.0$ & 13 & $P_{1}$ & $1.5 \pm 0.6$ & $3.9 \pm 0.9$ & $127 \pm 31$ & & & & & & & & & & $7.8 \pm 2.5$ & $1.5 \pm 0.5$ & $20 \pm 9$ \\
\hline $6.1-8.0$ & 21 & $P_{1}$ & $1.8 \pm 0.3$ & $4.2 \pm 0.8$ & $199 \pm 55$ & $59.9 \pm 6.3$ & $2.7 \pm 0.1$ & $0.49 \pm 0.08$ & $0.9 \pm 0.4$ & $0.07 \pm 0.05$ & $\mid 0.07 \pm 0.05$ & $0.02 \pm 0.01$ & $2.2 \pm 0.5$ & $2.8 \pm 1.2$ & $10.0 \pm 1.5$ & $1.7 \pm 0.5$ & $14 \pm 7$ \\
\hline $8.1-10.0$ & 25 & $P_{1}$ & $2.0 \pm 0.5$ & $4.9 \pm 1.0$ & $321 \pm 69$ & $74.1 \pm 6.9$ & $2.5 \pm 0.3$ & $|0.50 \pm 0.10|$ & $1.2 \pm 0.6$ & $0.09 \pm 0.08$ & $0.09 \pm 0.08$ & $0.02 \pm 0.01$ & $2.5 \pm 0.8$ & $3.3 \neq 1.1$ & $10.3 \pm 2.8$ & $1.9 \pm 0.4$ & $21 \pm 12$ \\
\hline $10.1-12.0$ & 53 & $p_{2}$ & $2.7 \pm 0.7$ & $5.2 \pm 1.3$ & $494 \pm 137$ & $92.7 \pm 11.7$ & $2.3 \pm 0.4$ & $0.85 \pm 0.19$ & $2.5 \pm 1.1$ & $0.35 \pm 0.22$ & $0.35 \pm 0.22$ & $0.07 \pm 0.05$ & $5.2 \pm 1.7$ & $4.7 \pm 1.6$ & $12.6 \pm 3.6$ & $2.0 \pm 0.5$ & $41 \pm 46$ \\
\hline $12.1-14.0$ & 51 & $P_{2}$ & $3.4 \pm 0.8$ & $6.2 \pm 2.0$ & $628 \pm 150$ & $110.0 \pm 20.2$ & $2[2.6 \pm 0.4$ & $1.01 \pm 0.16$ & $3.3 \pm 1.3$ & $0.54 \pm 0.32$ & $0.54 \pm 0.32$ & $0.20 \pm 0.20$ & $5.9 \pm 3.4$ & $4.8 \pm 1.3$ & $13.6 \pm 3.1$ & $2.5 \pm 0.8$ & $131 \pm 172$ \\
\hline $14.1-16.0$ & 26 & $p_{3}$ & $4.1 \pm 1.0$ & $8.6 \pm 2.4$ & $811 \pm 155$ & $155.8 \pm 27.7$ & $72.7 \pm 0.5$ & $1.31 \pm 0.34$ & $5.2 \pm 2.0$ & $1.80 \pm 0.31$ & {$\left[\begin{array}{l}1.80 \pm 0.3 \mathrm{I}\end{array}\right.$} & $1.03 \pm 0.30$ & $16.2 \pm 2.7$ & $5.1 \pm 2.7$ & $15.8 \pm 4.1$ & $3.1 \pm 0.7$ & $328 \pm 211$ \\
\hline $16.1-18.0$ & 10 & $P_{4}$ & $5.0 \pm 0.5$ & $9.9 \pm 1.7$ & $967 \pm 28$ & $189.2 \pm 19.1$ & $12.9 \pm 0.4$ & & & & & & & & $15.7 \pm 3.5$ & $4.1 \pm 1.1$ & $532 \pm 191$ \\
\hline $18.1-20.0$ & 6 & $P_{6}$ & $5.0 \pm 0.3$ & $11.0 \pm 1.1$ & 992 & $189.6 \pm 19.4$ & $42.8 \pm 0.3$ & & & & & & & & $20.2 \pm 6.1$ & $3.6 \pm 0.6$ & $564 \pm 157$ \\
\hline $20.1-25.0$ & 30 & $p_{6}$ & $5.2 \pm 0.6$ & $12.4 \pm 1.6$ & 1000 & $190.1 \pm 20.0$ & $2.8 \pm 0.3$ & & & & & & & & $17.0 \pm 3.9$ & $4.2 \pm 1.0$ & $605 \pm 194$ \\
\hline
\end{tabular}

1 This represents the stage of puberty most prevalent in each age group.

217-KS: 17-ketosteroids.

3 DHA : dehydroepiandrosterone.

417-OHCS: 17-hydroxycorticosteroids.

$5 \mathrm{FSH}$ : follicle-stimulating hormone.

LH: luteinizing hormone.

Mean \pm standard deviation 
Table II. Girculating testostcrone, $\mathrm{FSH}^{1}$ and $\mathrm{LH}^{2}$ concen trations in males at different stages of puberty

\begin{tabular}{|c|c|c|c|c|}
\hline Stage & No. & $\begin{array}{l}\text { Plasma testosterone } \\
\text { concentration }(\mathrm{ng} \%)\end{array}$ & $\begin{array}{l}\text { Serum FSH concentration } \\
(\mu \mathrm{g} \text { LER }-907 / 100 \mathrm{ml})\end{array}$ & $\begin{array}{l}\text { Serum LH concentration } \\
(\mu \mathrm{g} L E R-907 / 100 \mathrm{ml})\end{array}$ \\
\hline$P_{1}$ & 94 & $17 \pm 1^{3}$ & $9.7 \pm 0.4$ & $1.7 \pm 0.1$ \\
\hline$P_{2}$ & 56 & $97 \pm 5$ & $12.8 \pm 0$ & $2.2 \pm 0$ \\
\hline$P_{3}$ & 30 & $121 \pm 17$ & $13.5 \pm 0.7$ & $2.5 \pm 0.2$ \\
\hline$P_{4}$ & 20 & $403 \pm 42$ & $17.2 \pm 1.0$ & $3.0 \pm 0.2$ \\
\hline$P_{5}$ & 53 & $578 \pm 27$ & $16.5 \pm 0.6$ & $4.0 \pm 0.2$ \\
\hline
\end{tabular}

1 FSH : follicle-stimulating hormone.

${ }^{2} \mathrm{LH}$ : luteinizing-hormone.

${ }^{3}$ Mean \pm standard error of the mean.

4 Significance of difference between means determined by Student's $t$ test.

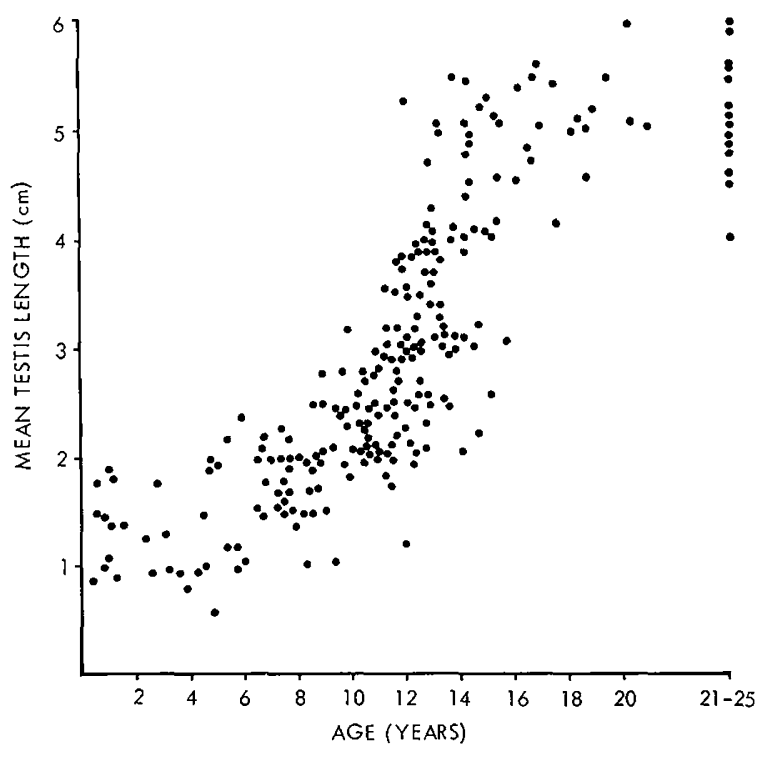

Fig. 1. Testis size (mean of the longest diameters of both testes) at different ages.

one was reflected in the rising creatinine excretion and wholebody ${ }^{40} \mathrm{~K}$ content after age 12 . As expected, there was a striking rise in urinary estrogens and 17-ketosteroids at this time. Plasma testosterone levels showed a significant correlation with both urinary estrogen $(r$ $=0.75, P<0.001)$ and 17-ketosteroid $(r=0.63, P<$ $0.001)$ content. Urinary 17-hydroxycorticosteroids in- creased gradually in each age group, with no noticeable spurt at puberty.

Serum FSH concentrations continued to rise during this period, but the slope was not significantly greater than that seen during the preadolescent years $(t=$ $1.15, P>0.1)$. On the other hand, there was a significant increment in the slope of the serum $L H$ rise after age $12(t=4.76, P<0.001)$.

\section{The Young Adult}

Mean serum FSH and LH levels ceased to rise after about age 16; similarly, there was no further change in mean testis size or in plasma testosterone concentration after this age. Clinically, most of the subjects in the 16-25-year-old age group were adult (stage $P_{5}$ ). Bone maturation was almost complete by age 17, and there was no further increase in mean whole body ${ }^{40} \mathrm{~K}$ content, showing that the period of rapid bone and muscle growth was completed.

The mean adult serum FSH level was approximately 2 times the mean prepubertal level, while the mean adult LH concentration was 3 times that in children. Although there was a significant correlation between plasma testosterone and both serum LH $(r=0.77, P$ $<0.001)$ and FSH $(r=0.57, P<0.001)$ when all age groups were considered together, there was no correlation between testosterone and either gonadotropin in the adult subjects. 


\section{Discussion}

The changing level of plasma testosterone with age parallels the pattern of testosterone glucuronide excretion in males [15, 22], and presumably is a reflection of gonadal testosterone production. The low levels seen in the prepubertal boys are not different from those found in girls, or in hypopituitary or castrate children [51], and would appear to arise from a source other than the testis. This is in keeping with the absence of characteristic functioning Leydig cells in the prepubertal human testis $[1,6,28,44]$. It should be noted, however, that minimal increments with time at these low testosterone levels might by obscured in a cross-sectional study such as this. At puberty there is a relatively rapid rise in plasma testosterone which coincides with, and is undoubtedly responsible for, the appearance of male secondary sexual characteristics, an adolescent growth spurt, and progressive epiphyseal maturation with eventual fusion. Coincident with this there



Fig. 2. Plasma testosterone concentrations in males at different ages. The shaded area represents the limit of sensitivity of the assay.

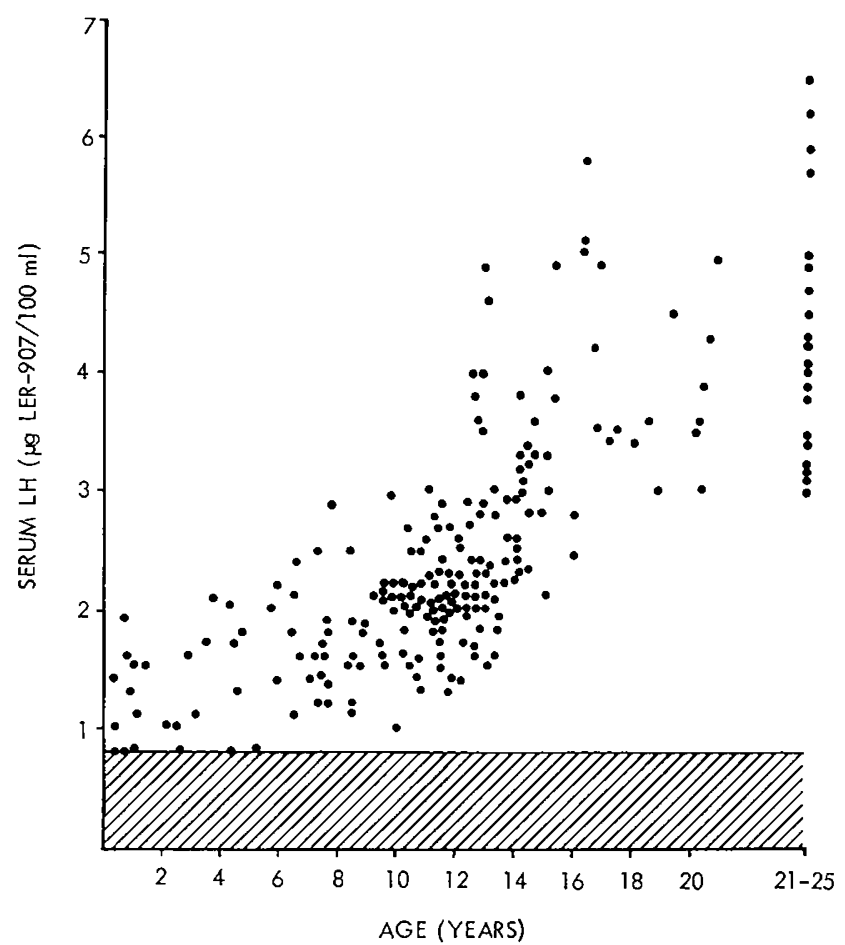

Fig. 3. Serum luteinizing hormone $(\mathrm{LH})$ concentrations in males at different ages. The shaded area represents the limit of sensitivity of the radioimmunoassay.

is a rise in estrogen and 11-deoxy-17-ketosteroid excretion.

Since testicular testosterone production is thought to be gonadotropin-, and primarily LH-dependent, a similar pattern in serum gonadotropin levels might be expected, with pituitary secretion of FSH and LH being initiated at about age 11. Instead, beginning around age 6-8 years, there is a gradual rise in mean FSH and LH concentration. The FSH appears to rise gradually from age 6 to age 15, with no apparent pubertal spurt. Mean serum LH levels begin to rise about age 8 , with a more abrupt increase after age 12 . This finding, that $\mathrm{LH}$ levels begin to rise several years before plasma testosterone, suggests either that testosterone secretion is related to the attainment of a threshold LH concentration (approximately $2.2 \mu \mathrm{g} /$ $100 \mathrm{ml}$ ) or that the testis at puberty becomes progressively more sensitive to a slight increment in LH stimulation.

The pattern of rising gonadotropin levels in late childhood resembles that for testis growth (Fig. 1). During this time, although typical Leydig cells are absent, the testis is not a static organ; progressive changes are seen in the seminiferous tubules, as the sex 


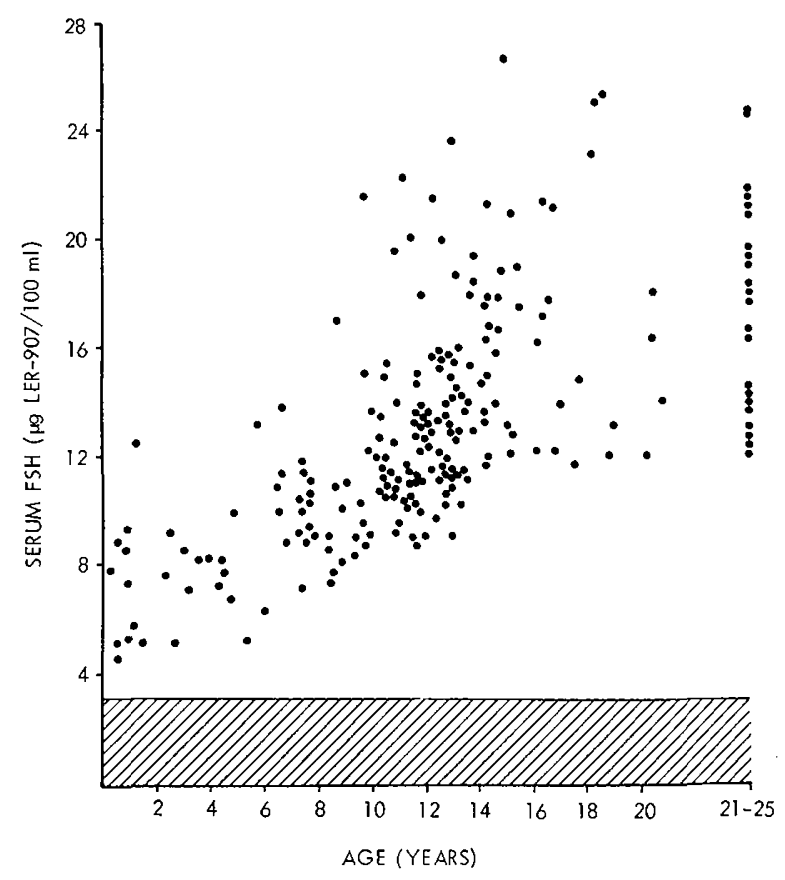

Fig. 4. Serum follicle-stimulating hormone (FSH) concentrations in males at different ages. The shaded area represents the limit of sensitivity of the radioimmunoassay.

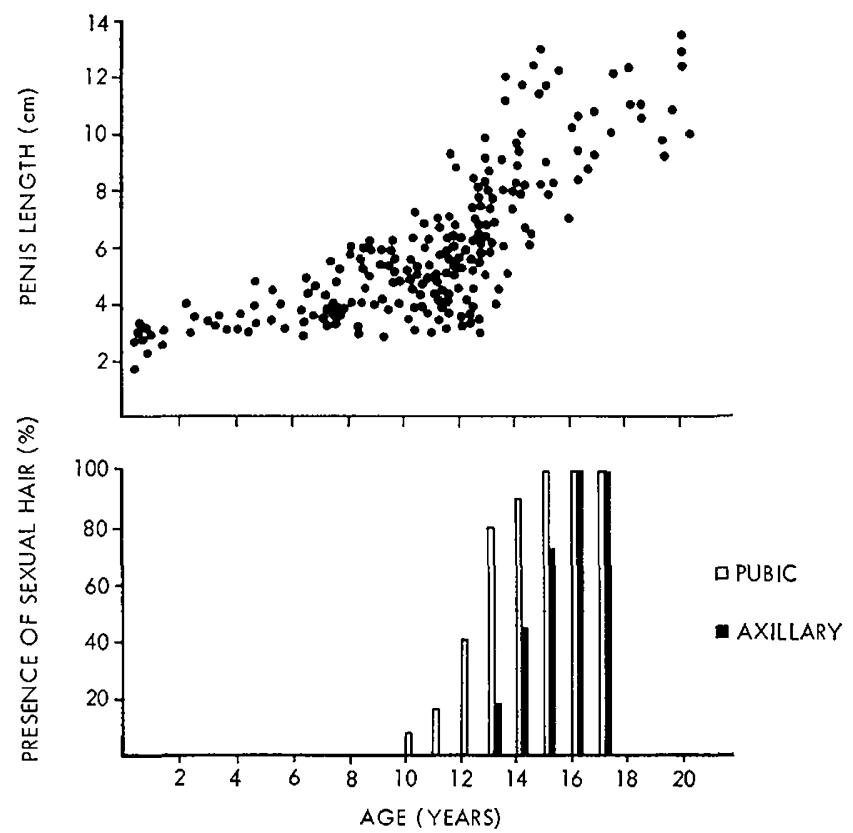

Fig. 5. Lax penis length in males at various ages (top); the percentage of subjects showing pubic or axillary hair, or both, at these ages (bottom).

cords grow and acquire a lumen and the germ cells mature to the spermatogonial stage $[1,6,27,44]$. It is possible that these changes are gonadotropin-mediated since the testis in hypogonadotropic hypogonadism shows small lumenless tubules, and only primitive germ cells [16]. Similar maturational changes may be proceeding in the Leydig cell precursors which render them progressively more responsive to $\mathrm{LH}$ stimulation.

These studies have not explored the role of adrenal androgen secretion in male adolescence directly. However, it is known [37, 39] that plasma levels of dehydroepiandrosterone sulfate rise progressively after age 7 , a pattern resembling that seen in serum gonadotropin concentrations. This may suggest that adrenal androgen production, at least in late childhood, could be gonadotropin-dependent.

In Figure 6, a schematic summary of the changes in circulating gonadotropins in relation to adolescent development is shown. It can be seen that, by age 10 , the mean FSH concentration has entered the adult range. After age 12 there is a relatively greater rise in $\mathrm{LH}$ levels, with the adult range being reached around age 15. This pattern supports a model in which FSH plays a role primarily in testis growth and tubular development, with Leydig cell function being primarily LHdependent. No information is available from these data regarding the roles of $\mathrm{FSH}, \mathrm{LH}$, and testosterone

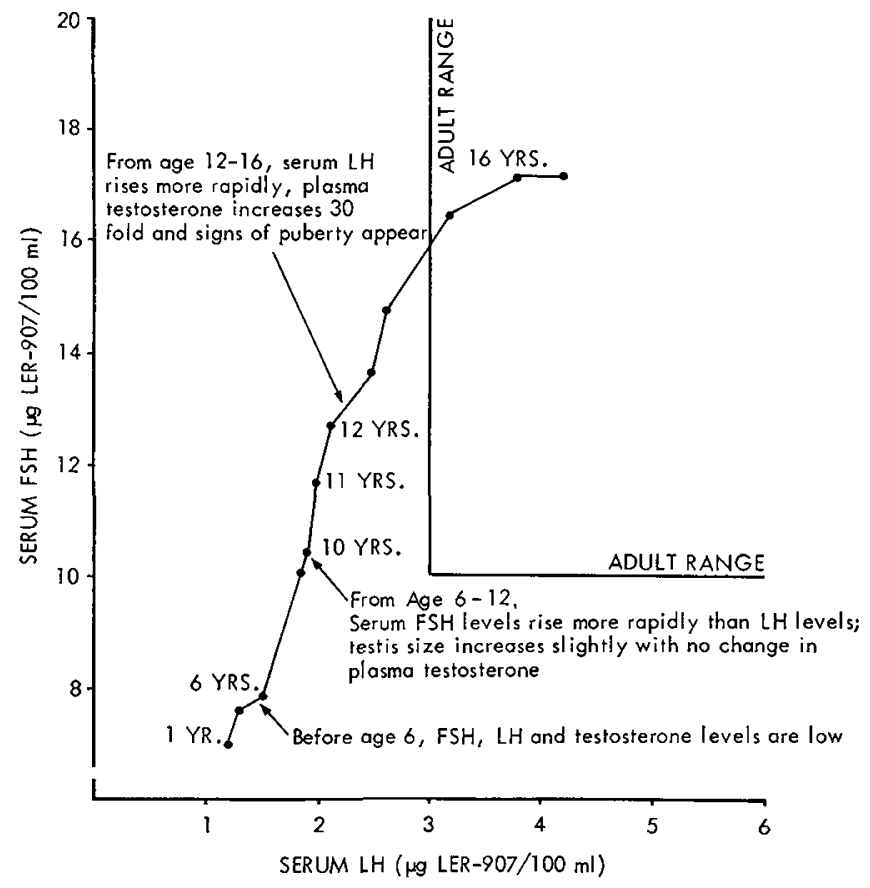

Fig. 6. A schematic representation of the relationship between mean serum follicle-stimulating hormone (FSH) and luteinizing hormone (LH) concentrations in males at various ages. The sequential phenomena of puberty are shown. 
in the final maturation of spermatozoa, nor their feedback interrelations [19].

This pattern of pituitary-gonadal development in man parallels in some respects that seen in other species. In the rat, testis growth begins at 20 days of age, possibly as a result of FSH stimulation [33]. Signs of testosterone effect appear at 45-50 days [17, 30]. Studies of pituitary gonadotropin content show that FSH content rises early, reaching adult levels by day 33 , while LH levels peak between days 43 and 47 [23, 25]. By day 33, coincident with the FSH rise, the activities of the testicular enzymes related to testosterone biosynthesis reach the adult range, but testosterone secretion does not occur [17] because of a corresponding rise in the activity of testicular reductases [45]. Around 45 days, as LH levels peak, there is a rapid fall in reductase activity and testosterone secretion begins. There is also evidence that in the canine testis the synergistic effects of FSH and $\mathrm{LH}$ are required for androgen production [8].

\section{Summary}

Circulating levels of FSH, LH, and testosterone were measured in 253 healthy males aged 3 months-25 years. These data were correlated with the stage of pubertal development, lean body mass (by whole body ${ }^{40} \mathrm{~K}$ counting), bone maturation (from a wrist $x$-ray), and 24-hr excretion of creatinine, estrogens, 17-hydroxycorticosteroids, total 17-ketosteroids, and fractionated 11deoxy-17-ketosteroids in urine. The data show that mean serum FSH and LH levels begin to rise at around age 6-8 years, signaled by slight testicular enlargement, but no rise in plasma testosterone. The onset of somatic puberty is accompanied by a steeper increase in serum LH, and a 20 -fold rise in plasma testosterone. Circulating $\mathrm{LH}$ and testosterone continue to rise until about age 17 , while serum FSH reaches a plateau somewhat earlier.

The data suggest that the testis in late childhood may undergo progressive maturation under the influence of gradually rising gonadotropin levels. The relatively abrupt initiation of gonadal testosterone secretion at puberty appears to follow the achievement of a critical threshold concentration of circulating LH.

\section{References and Notes}

1. Albert, A., Underdahl, L. O., Greene, L. F., and Lorenz, N.: Male hypogonadism. I. The normal testis. Proc. Staff Meet. Mayo Clin., 28: 409 (1953).
2. August, G. P., TKachuk, M., and Grumbach, M. M.: Plasma testosterone-binding affinity and testosterone in umbilical cord plasma, late pregnancy, prepubertal children, and adults. J. Clin. Endocrinol. Metab., 29: 891 (1969).

3. Baghdassarian, A., Guyda, H., Johanson, A., Migeon, C. J., AND BluzZARD, R. M.: Urinary excretion of radioimmunoassayable luteinizing hormone $(\mathbf{L H})$ in normal male children and adults, according to age and stage of sexual development. J. Clin. Endocrinol. Metab., 31: 428 (1970).

4. Buckler, J. M. H., and Clayton, B. C.: Output of luteinizing hormone in the urine of normal children and those with advanced sexual development. Arch. Dis. Childhood, 45: 478 (1970).

5. Burr, I. M., Sizonenko, P. C., Kaplan, S. L., and Grumbach, M. M.: Hormonal changes in puberty. I. Correlation of serum luteinizing hormone and follicle stimulating hormone with stages of puberty, testicular size, and bone age in normal boys. Pediat. Res., 4: 25 (1970).

6. Charny, C. W., Conston, A. S., and Meranze, D. R.: Development of the testis: a histologic study from birth to maturity with some notes on abnormal variations. Fert. Steril., 3: 461 (1952).

7. Eechaute, W., and Demeester, G.: Fluorimetric determination of total estrogens after gel filtration of enzymatically hydrolyzed urine. J. Clin. Endocrinol. Metab., 25: 480 (1965).

8. Erk-Nes, K. B.: Factors influencing the secretion of testosterone in the anaesthetized dog. Ciba Found. Colloq. Endocrinol., 16: 120 (1967).

9. FaIMAN, C., AND RXAN, R. J.: Radioimmunoassay for human follicle stimulating hormone. J. Clin. Endocrinol. Metab., 27: 444 (1967).

10. FaIman, C., AND RYAN, R. J.: Radioimmunoassay for human luteinizing hormone. Proc. Soc. Exp. Biol. Med., 125: 1130 (1967).

11. Fitschen, W., and Clayton, B. E.: Urinary excretion of gonadotropins with particular reference to children. Arch. Dis. Childhood, 40: 16 (1965).

12. Forbes, G. B., ANo LewIs, A. M.: Total sodium, potassium and chloride in adult man. J. Clin. Invest., 35: 596 (1956).

13. Frasier, S. D., Gafford, F., and Horton, R.: Plasma androgens in childhood and adolescence. J. Clin. Endocrinol. Metab., 29: 1404 (1969).

14. Gandy, H. M., And Peterson, R. E.: Measurement of testosterone and 17 -ketosteroids in plasma by the double isotope dilution derivative technique. J. Clin. Endocrinol., Metab., 28: 949 (1968).

15. Gupta, D., AND Butler, H.: Excretion of testosterone and epitestosterone glucuronides in pre-school, pre-adolescent and adolescent children. Steroids, 14: 343 (1969).

16. Howard, R. P., Sniffen, R. C., Simmons, F. A., ANd ALBRIGHT, F.: Testicular deficiency: a clinical and pathologic study. J. Clin. Endocrinol. Metab., 10: 121 (1950).

17. InANo, H., HoRI, Y., AND TAMAOKI, B-X.: Effect of age on testicular enzymes related to steroid bioconversion. Ciba Found. Colloq. Endocrinol., 16: 105 (1967).

18. Johanson, A. J., Guyda, H., Light, C., Mrgron, C. J., ANd Blyzzard, R. M.: Serum luteinizing hormone by radioimmunoassay in normal children. J. Pediat., 74: 416 (1969).

19. Johnsen, S. G.: The stage of spermatogenesis involved in the testicular-hypophyseal feed-back mechanism in man. Acta Endocrinol., 64: 193 (1970). 
20. Jungmann, R. A., Calvary, E., And Schweppe, J. S.: Quantitative analysis of urinary 11-desoxy-17-ketosteroids and pregnanediol by gas-liquid chromatography. J. Clin. Endocrinol. Metab., 27: 355 (1967).

21. Kenny, F. M., Midgley, A. R., Jaffe, R. B., Garces, L. Y., AND VASQUEZ, A.: Radioimmunoassay of luteinizing hormone (LH) and follicle-stimulating hormone (FSH) in normal children and various abnormal conditions. (Abstract). J. Pediat., 72: 565 (1968).

22. KNoRr, D.: Uber die Ausscheidung von freiem und glucuronsauregebundenem Testosteron im Kindes-und Reifungsalter. Acta Endocrinol., 54: 215 (1967).

23. Kragt, C. L., and Ganong, W. F.: Pituitary FSH content in male rats at various ages. Proc. Soc. Exp. Biol. Med., 128: 965 (1968).

24. Kulin, H. E., Rifkind, A. R., Ross, G. T., AND Odell, W. D.: Total gonadotropin activity in the urine of prepubertal children. J. Clin. Endocrinol. Metab., 27: 1123 (1967).

25. Labhsetwar, A. P.: Age-dependent changes in pituitarygonadal relationships. J. Reprod. Fert., 21: 407 (1970).

26. LeE, P. A., Midgley, A. R., JR., AND JAFFe, R. B.: Regulation of human gonadotropins. VI. Serum follicle stimulating and luteinizing hormone determinations in children. J. Clin. Endocrinol. Metab., 31: 248 (1970).

27. Mancini, R. E., Narbaitz, R., and Lavieri, J. C.: Origin and development of the germinative epithelium and Sertoli cells in the human testis: cytological, cytochemical, and quantitative study. Anat. Rec., 136: 477 (1960).

28. Mancini, R. E., Vilar, O., Lavieri, J. C., Andrada, J. A., and HeINRICH, J. J.: Development of Leydig cells in the normal human testis. Amer. J. Anat., 112: 203 (1963).

29. McRoberts, J. W., Olson, A. D., and Herrmann, W. L.: Determination of urinary testosterone and epitestosterone in man, woman, and children. Clin. Chem., 14: 565 (1968).

30. NiEmi, M., AND IKonfn, M.: Histochemistry of the Leydig cells in the postnatal prepubertal testis of the rat. Endocrinology, 72: 443 (1963).

31. Odell, W. D., Ross, G. T., and Rayford, R. L.: Radioimmunoassay for luteinizing hormone in human plasma or serum: physiological studies. J. Clin. Invest., 46: 248 (1967).

32. Peterson, R. E., and Pierce, C. E.: Methodology of urinary 17-ketosteroids. In: F. W. Sunderman and F. W. Sunderman, Jr.: Lipids and the Steroid Hormones in Clinical Medicine, p. 147. (Lippincott, Philadelphia, 1960).

33. Petrusz, P., Robyn, C., ANd Diczfalusy, E.: Biological effects of human urinary follicle stimulating hormone. Acta Endocrinol., 63: 454 (1970).

34. Raiti, S., Johanson, A., Lrght, C., Migeon, C. J., And Blizzard, R. M.: Measurement of immunologically reactive follicle stimulating hormone in serum of normal male children and adults. Metabolism, 18: 234 (1969).

35. Rarri, S. M. B., Light, C., AND BlizzaRd, R. M.: Urinary FSH excretion in boys and adult males as measured by radioimmunoassay. J. Clin. Endocrinol. Metab., 29: 884 (1969).

36. Root, A. W., Moshang, T., JR., Bonglovanni, A. M., ANd EberLein, W. R.: Concentrations of plasma luteinizing hormone in infants, children, and adolescents with normal and abnormal gonadal function. Pediat. Res., 4: 175 (1970).

37. Rosenfield, R. L., and Ebrrlein, W. R.: Plasma 17-ketosteroid levels during adolescence. J. Pediat., 74: 932 (1969).

38. Ryan, R. J., Cloutier, M. D., Hayles, A. B., Paris, J., AND
RANDALL, R. V.: The clinical utility of radioimmunoassays for serum follicle-stimulating hormone (FSH) and luteinizing hormone (LH). Med. Clin. N. Amer. 54 : 1049 (1970).

39. SaEz, J. M., AND Bertrand, J.: Studies on testicular function in children: plasma concentrations of testosterone, dehydroepiandrosterone and its sulfate before and after stimulation with human chorionic gonadotropin. Steroids, 12: 749 (1968).

40. Saxena, B. B., Demura, H., Gandy, H. M., and Peterson, R. E.: Radioimmunoassay of human follicle stimulating and luteinizing hormones in plasma. J. Clin. Endocrinol. Metab., 28: 519 (1968).

41. Schaich, D. S., Bryson, M. F., ANd LeE, L. A.: Plasma follicle stimulating hormone levels in normal children and in children with various pituitary or gonadal disorders (Abstract). Pediat. Res., 2: 308 (1968).

42. Schalch, D. S., Parlow, A. F., Boon, K. C., and Reichlin, S.: Measurement of human luteinizing hormone in plasma by radioimmunoassay. J. Clin. Invest., 47:665 (1968).

43. ScIARRA, N., AND LEONE, U.: Urinary excretion of luteinizing hormone in boys and adult men. J. Endocrinol., 46: 229 (1970).

44. Sniffen, R. C.: Histology of the normal and abnormal testis at puberty. Ann. N.Y. Acad. Sci., 55: 609 (1952).

45. Strickland, A. L., Nayfeh, S. N., and French, F. S.: Conversion of cholesterol to testosterone and androstanediol in testicular homogenates of immature and mature rats. Steroids, 15: 373 (1970).

46. Sunderman, F. W., JR.: Methodology of urinary 17-hydroxycorticosteroids. In: F. W. Sunderman and F. W. Sunderman, Jr.: Lipids and the Steroid Hormones in Clinical Medicine, p. 162. (Lippincott, Philadelphia, 1960).

47. Tanner, J. M., Whitehouse, R. H., and Healy, M. J. R.: A new system for estimating skeletal maturity from the hand and wrist, with standards derived from a study of 2600 healthy British children. International Children's Centre, Paris, 1962.

48. Van Baelen, H., Heyno, W., ANd DeMoor, P.: Measurement of urinary estrogens using adsorption on Sephadex. J. Clin. Endocrinol. Metab., 27: 1056 (1967).

49. VestergaArd, P., RaAbo, E., ANd Veds $\varnothing$, S.: Determination of urinary testosterone in men, women and children. Clin. Chim. Acta, 14: 540 (1966).

50. Wieland, R. G., Yen, S. S. C., and Pohtman, C.: Serum testosterone levels and testosterone binding affinity in prepubertal and adolescent males; correlation with gonadotropins. Amer. J. Med. Sci., 259: 358 (1970).

51. WinTER, J. S. D.: unpublished observations.

52. Winter, J. S. D., ANd Grant, D. R.: A rapid and sensitive assay for plasma testosterone in adults and children. Anal. Biochem. (in press).

53. YEN, S. S. C., AND VICIC, W. J.: Serum follicle-stimulating hormone levels in puberty. Amer. J. Obstet. Gynecol., 106: 134 (1970).

54. Yen, S. S. C., Vicic, W. J., AND Kearchner, D. V.: Gonadotropin levels in puberty. I. Serum luteinizing hormone. J. Clin. Endocrinol. Metab., 29: 382 (1969).

55. The LER-907 human pituitary gonadotropin standard was a gift of the National Pituitary Agency.

56. The authors would like to acknowledge the kind cooperation of the Winnipeg Hebrew School, the Manitoba Training School and the Children's Aid Society of Winnipeg.

57. The authors would like to thank: Mr. I. Riyaz, Mr. D. R. 
Grant and Mrs. F. A. Smale for excellent technical assistance; Dr. W. Reid for the whole body ${ }^{40} \mathrm{~K}$ counting; Miss J. Emmett and Dr. O. Amatayakul for general assistance at every stage; and Dr. J. A. Moorhouse for encouragement and guidance. 58. Presented in part at the Fifty-second Meeting of the Endocrine Society, St. Louis, Mo., June 11, 1970.

59. Supported by Medical Research Council of Canada Grants nos. MA-2850 and MA-2997, and the Children's Hospital Research Foundation. Dr. Faiman is a Medical Research Council Scholar.

60. Requests for reprints should be addressed to: Jeremy $S$. D. Winter, The Children's Hospital of Winnipeg, 685 Bannatyne Avenue, Winnipeg 3, Manitoba, Canada.

61. Accepted for publication May 13, 1971 . 